\title{
Developing Mathematical Students Worksheet Based On Islamic Values Using Contextual Approach
}

\author{
${ }^{1}$ Choirudin Choirudin, ${ }^{1}$ Eka Fitria Ningsih, ${ }^{1}$ M. Saidun Anwar, ${ }^{2}$ Ani Choirunnisa, ${ }^{3}$ Apri \\ Wahyudi, ${ }^{4}$ Andino Maseleno, ${ }^{5}$ Ayshwarya Baburan and ${ }^{6}$ Phong Thanh Nguyen \\ ${ }^{1}$ IAIMNU Metro Lampung, Indonesia \\ 2 Univeritas Lampung, Indonesia \\ ${ }^{3}$ STIT Pringsewu Lampung, Indonesia \\ ${ }^{4}$ Institute of Information and Computing in Energy, University Tenaga Nasional, Malaysia \\ 5Department of Computer Science, Kristu Jayanti College, Bangalore-560043, India \\ 6 Department of Project Management, Ho Chi Minh City Open University (HCMCOU), Vietnam \\ e-mail: choirudiniaimnumetro@gmail.com
}

\begin{abstract}
Development of worksheets looks like the beginning of the problems found in schools, students have difficulty to understanding mathematical material both calculation concepts and moral values those have not been well organized. Worksheet designed with using a contextual approach which contains collaboration between material and verses relating to the used material, so that moral values related to the material are obtained and equipped with the application of moral values in the form of problem examples. After being designed, product is developed to be LKPD. The study objectives include: To develop a Mathematics LKPD based on Islamic values on the subject of algebraic. As a result of the study, the development of Student Worksheet (LKPD) based on Islamic values using a contextual approach to the subject of algebraic in class VII of the Qur'an Science Junior High School MinhajuthThullabPekalongan. The research uses the 4D development model consists of 4 main stages: Define, Design, Develop and Disseminate. The response of teachers to LKPD based on Islamic values with using a contextual approach on the subject of the algebra score $82 \%$ with very interesting criteria. The responses of students to LKPD obtained a score of $80 \%$ with very decent criteria.
\end{abstract}

Keywords: Mathematical Student Worksheet, 4D Model, Islamic Values, Contextual Approach

How to Cite: Choirudin et al. (2019). Developing Mathematical Students Worksheet Based On Islamic Values Using Contextual Approach. International Journal on Emerging Mathematics Education, 3(2), 152-161. http://dx.doi.org/10.12928/ijeme.v3i2.13286

\section{INTRODUCTION}

Education is an important requirement for human life, because with human education it can be someone who has character, knowledge and has high intellectual property in various ways. In the National Education System Law No. 20 Th. 2003 the aim of national education increases piety to God Almighty, intelligence, skills, enhance character, strengthen personality, strengthen the spirit of nationalism in order to grow human beings who can build themselves and share responsibility for national development (Departemen Pendidikan Nasional, 2009).

Efforts continue to be developed in order to realize an active learning while keeping up with technological developments (Ehwanudin et al., 2019). Education is also expected to improve the values of student religiosity by instilling religious values through general education. One way for the government to increase the value of student attitudes is to require schools to use 2013 curriculum (Apri Wahyudi et al., 2019). 
The concept of the 2013 curriculum is the character of goals or graduate competencies which are packaged in the form of integration by emphasizing character education, the character of learning that emphasizes a scientific and behavioral assessment approach that is more detailed by emphasizing assessment process (Shafa, 2014). So that both of them must be the foundation in every learning, especially in mathematics learning all of which are for the achievement of national education goals as stated in Law No. 20 of 2003 concerning the National Education System. National education functions to develop capabilities and form a dignified character and national civilization in order to educate the nation's life, aiming at developing potential students to become human beings who believe and fear God Almighty, have noble character, are healthy, knowledgeable, capable, creative, independent, and become a democratic and responsible citizen (Omeri, 2015).

Many students are passive in the learning process and still have uncontrolled moral values, most of which occur when students do not live in the cottage (Agustin et al., 2019). For example, there are some students who play truant, smoke, and are less sensitive to teachers. for students' learning achievement in mathematics learning is enough, but for their own morals it is still quite low. The use of instructional media is still a right of textbooks alone, so the goal K13 has not materialized as yet contained in textbooks religious values that should have started to be introduced to the students. Prasurvey which transactions are carried out based researcher on January 3, 2019 in the Junior Science Quran Pekalongan, conducted an interview with Ayuningtyas (2019) as the math teacher at the junior high school, she said for class VII had used the 2013 curriculum.

The learning aspects of mathematics include moral, social, knowledge, and skills. However, the most significant contribution to 2013 curriculum is the moral aspect in the formation of student character and personality. Basically Islamic values can be integrated in the process of learning mathematics, so a way is needed to formulate mathematical learning that integrates the value of Islam on the topics of school mathematics. Education is fundamental to the development of human life, and so mathematics education. For this reason perhaps mathematics a compulsory subject has been at all level of study (Mustafa, 2009). Specifically, the common objectives are to be able to understand and understand conceptual knowledge of contextual problems, design mathematical models, solve models, and interpret solutions (Retnowati, Fathoni, dan Chen, 2018).

So we know that students have not obtained the religious values contained in mathematics learning, even they do not yet know the purpose of mathematics learning in their daily lives. They considered the K13 learning model almost the same as KTSP, there was no significant change so that students felt that they were not motivated to learn more actively. Mathematical learning tends to emphasize cognitive aspects and not pay attention to moral and social aspects. Mathematics teachers must be able to collaborate mathematical material with Islamic values contained in it so that it can be applied by students in everyday life.

As research conducted by (Syaifuddin, 2017; Katz \& Stupel, 2015; Ningsih, E. F., 2017; Subandi Subandi et al., 2018) with the research title Development of Contextual Based Student Worksheets (LKPD) to Improve Mathematical Problem Solving and Self-Efficacy Capabilities. Previous research conducted explained that students using contextual based LKPD were more interactive, more able to solve mathematical problems according to their steps; students who use contextual-based LKPD are more confident and more interactive. The difference in this study is that LKPD is used based 
on Islamic values. One solution that needs to be implemented is to develop teaching materials in the form of LKPD especially in algebraic material, because in the subject of algebra the material contained in it is still general, in the form of addition, subtraction, multiplication, and possible distribution in daily life - day by students. The design of a good LKPD is needed to achieve a learning process that encourages students to play an active role (Munandar, 2015; Choirudin, 2017).

The student worksheet is one of the printed materials for papers containing materials, summaries, and instructions on the implementation of learning tasks that must be done by students who refer to basic competencies to be achieved (Basuki and Wijaya, 2018). The use of LKPD is one way that helps students to more actively construct their knowledge according to the demands in the 2013 curriculum (Anggraini, Anwar, and Madang, 2016). So it can be concluded that there is a need for the development of LKPD based on Islamic values through a contestative approach. Where by using a contextual approach can help students grow moral, cognitive, and affective attitudes.

The purpose of this study is: To develop a Mathematics Worksheet (LKPD) based on Islamic values on the subject of algebraic forms. To find out the response of teachers and students to mathematics LKPD based on Islamic values using a contextual approach to the subject of algebraic forms. To instill the attitude of religiosity of students towards mathematics learning on the subject of algebraic forms.

\section{RESEARCH METHOD}

The type of research used is Research \& Development (R\&D), because of this study aims to also investigate and sequence growth or change as a function of time (Narbuko and Achmadi, 2014). Development research is not the research intended for test theory but to produce certain products. The model used in this study is the 4-D (Four D Models) development model suggested by Thiagarajan and Semmel consisting of four stages, definition, design, develop, and dessiminate (Zakaria, Ismail, and Kiu, 2015). The products to be developed in this study are teaching materials contextual based mathematics to improve understanding skills the concept of class VII SMP students in the form of LKPD on the subject of algebraic forms.

\section{RESULTS AND DISCUSSION Product Define}

The purpose of this stage is to establish and determine the learning conditions which include learning objectives and restrictions on learning material (Sutarti, and Irawan, 2017; Choirudin, 2015). This step includes five steps: preliminary analysis, student analysis, concept analysis, task analysis and learning objectives. Teaching materials used by students are teaching materials in the form of 2013 curriculum student modules. The activities carried out are to bring up and establish the basic problems faced in junior high school mathematics learning in algebraic material. Researchers feel that the teaching materials used by students in the algebraic form material still have many weaknesses, namely in terms of language and content. The language used makes it difficult for students to understand the material in the form of algebra, while the contents only provide examples of questions in the abstract while the material in the form of algebra is material that occurs in everyday life (no application of the concept). As a result students only know the concept but not the application. Therefore, researchers want to develop other teaching materials, teaching materials in the form of LKPD (Anwar, 2015). The activity carried out at this stage is to

IJEME, Vol. 3, No. 2, September 2019, 152-161. 
examine the characteristics of students including the knowledge, skills and initial attitudes students have to achieve learning objectives based on core competencies. Task analysis is a collection of procedures for determining the content in teaching materials. The activity carried out is to outline the structure of the content of teaching materials, the steps that must be taken by students in the teaching material and outline the information obtained. The information in question is a problem that will be presented in teaching materials obtained from the internet or other supporting media. The activities carried out at this stage are outlining the concepts that must be discovered and studied by students in teaching materials. The concept in question is understanding problems related to algebraic forms. The LKPD based on Islamic which discusses material with algebraic material. The first stage in producing a product is to determine the potential and problems by conducting a field study and obtain information about potential that is available at school. Learning schools have not yet provided learning tools by utilizing technological developments such as LCD and projectors on classes so that learning media is increasingly diverse, but there are not many learning media that are in accordance with the 2013 curriculum.

The material used in the printed book only covers subject matter in general, not yet related to Islamic values so that students only get knowledge in general. Therefore, the researchers developed Islamic Based LKPD, so that students get the knowledge of religion as well as getting general knowledge. Below are the initial products used in the Qur'an Science Junior High School Minhajuth Thullab Pekalongan. After the potential and problems are completed, the next step is to gather information. This information collection is very important to find out the needs of students for products developed through research and development. The first step is to collect data in the Qur'an Science Junior High School Minhajuth Thullab Pekalongan to educators and students especially class VII in the form of interviews with Ibu Okta Ayuningtyas, S.Pd to find out information that will be carried out in the research and development process.

\section{Product Design}

After gathering information, the next step is product design. There are some that are done at the product design stage of the development of Islamic Based LKPD in Class VII algebraic material. The steps for compiling this LKPD design include adjusting Core Competencies and Basic Competencies and syllabus based on the 2013 Curriculum. LKPD based on Islamic uses Quarto paper sizes, 1.5 space scales, Times New Roman fonts, Traditional Arabic, and Islamic values and the verses of the Qur'an.
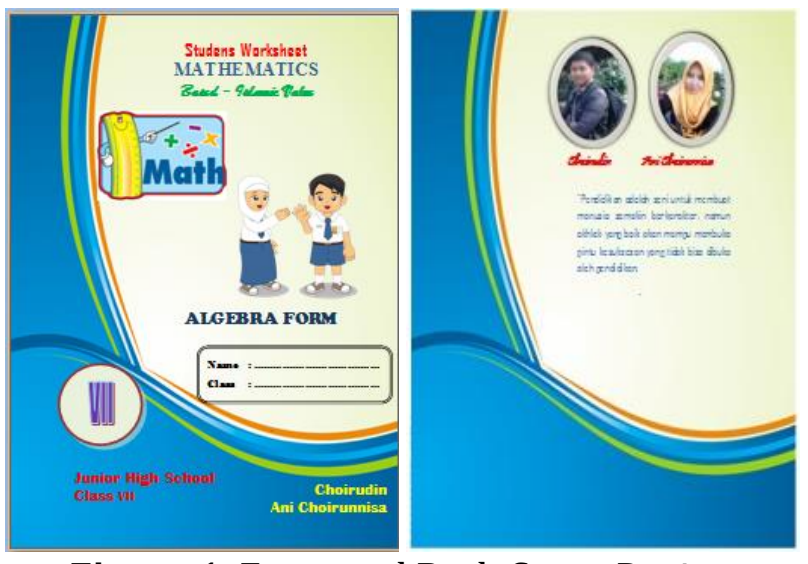

Figure 1. Front and Back Cover Design 
The product design of LKPD development consists of front cover and back cover, LKPD development team page, usage instructions, preface, table of contents. This LKPD consists of core competencies, basic competencies, learning objectives, activity instructions.

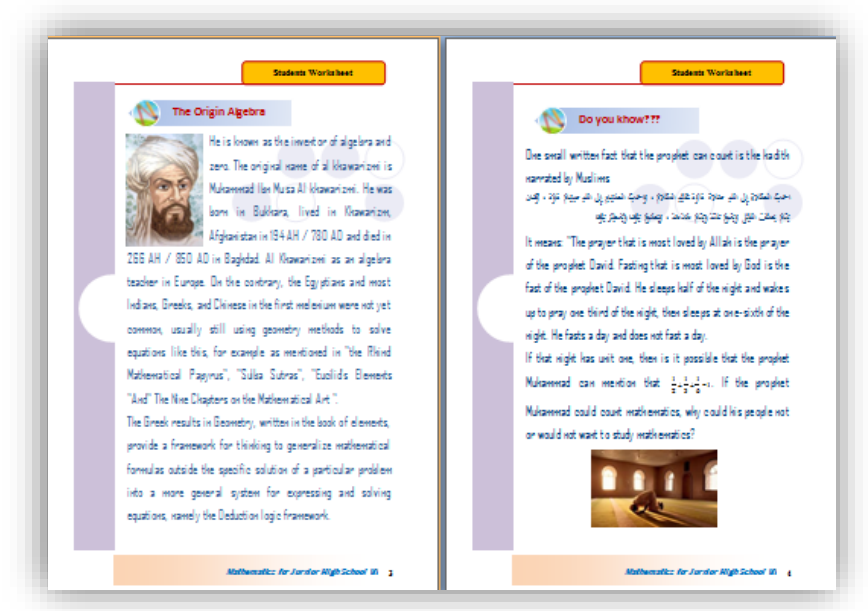

Figure 2. Islamic values and verse Al-Qur'an for Material

In teaching materials in the form of LKPD especially in general algebraic material contained the form of addition, subtraction, multiplication, and possible distribution in daily life - day by students. The design of a good Student Worksheet (LKPD) is needed to achieve a learning process that encourages students to play an active role.

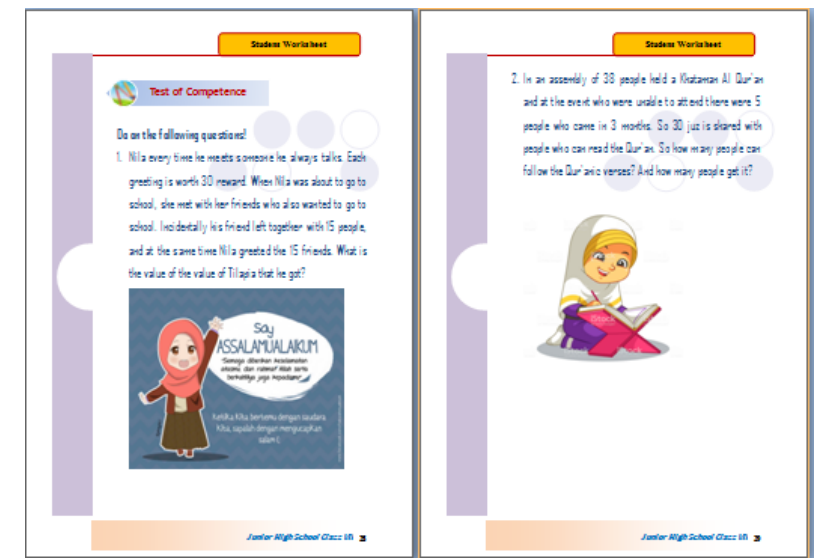

Figure 3. Test of Competences Based Islamic Contextual Approach

In evaluation questions, developing test of competences students worksheet based on islamic values using contextual approach. As a result educators there is very little to give an understanding of Islam, not even at all discussing or applying one core competency which is competence about spiritual child.

Research and development of Student Worksheets that have been designed, are then validated by several experts: 1) Mrs. Okta Ayuningtyas, S.Pd., the teacher of seventh grade of the Qur'an Science Junior High School Minhajuth Thullab Pekalongan and 2) Mr. Hanif Amrullah ZA., M.Si., lecturer IAIM NU Metro Lampung. Validation was also carried out to obtain input, suggestions, opinions and evaluation of the developed LKPD. The results of the validation of material experts, media experts, linguists, and validation of practitioners in the field of material experts are in Table 1. 
Table 1. Material Validation Experts

\begin{tabular}{lcl}
\hline \multicolumn{1}{c}{ Assessment Indicator } & Percentage & \multicolumn{1}{c}{ Criteria } \\
\hline Indicator Competency & $80 \%$ & Feasible \\
Material accuracy & $94 \%$ & Very Feasible \\
Material update & $90 \%$ & Very Feasible \\
Encourage curiosity & $80 \%$ & Feasible \\
Integrated Islamic Values & $90 \%$ & Very Feasible \\
\hline \multicolumn{1}{c}{ Average } & $87 \%$ & Feasible \\
\hline
\end{tabular}

Table 1 is the result of stage 1 validation by material experts for the feasibility of teaching materials in the form LKPD Based on Islamic. On the indicator of conformity assessment of material with $\mathrm{KI}$ and KD obtained results with $80 \%$ percentage on indicators of assessment of material accuracy obtained results with $94 \%$ presentation on indicators of material recent assessment obtained results with $90 \%$ presentation on assessment indicators encourage curiosity obtained results with $80 \%$ percentage and at results of integrated assessment of Islamic values are obtained with a percentage of $90 \%$ so that the total average percentage of material validation stage 1 is $87 \%$ included in the feasible category to be tested and obtain suggestions for improvement as follows:

Media expert validation aims to test the presentation of Islamic Based LKPD. The validator who became a media expert was Mr. Hanif Amrullah ZA., M.Pd, as a lecturer at IAIM NU Metro Lampung. The results of phase 1 media validation data can be seen in Table 2.

Table 2. Media Validation Experts

\begin{tabular}{|c|c|c|}
\hline Assessment Indicator & Percentage & Criteria \\
\hline Size of LKPD & $80 \%$ & Very Feasible \\
\hline LKPD Cover Design & $91 \%$ & Very Feasible \\
\hline Design the contents of the LKPD & $89 \%$ & Very Feasible \\
\hline Average & $86 \%$ & Very Feasible \\
\hline
\end{tabular}

Table 2 is the result of stage 1 validation by media experts for the feasibility of teaching materials in the form of Islamic Based LKPD. In the aspect of LKPD size results obtained with a percentage of $80 \%$ in the aspects of the LKPD cover design obtained results with 91\% presentation and in the design aspect of the LKPD content results obtained with presentation $89 \%$ so that the total average percentage of media validation stage 1 was $86,94 \%$ included in the category is very feasible to be tested (Lubisand Zubaedi, 2013).

After product design is validated through the assessment of material experts, media experts, and class VII teacher. The researcher revised the product design developed based on the expert's input.

\section{Product Develop}

After the product through the validation stage by material experts, media experts and linguists have been repaired, then the product is tested with a small-scale trial consisting of 12 students, field tests consisting of 30 students, while the product trial results are as follows: 
In a small-scale trial intended to test product attractiveness, students in this small-scale test looked at the LKPD given, and at the end of the product trial involving 12 heterogeneous selected students based on their ability in class and gender then students were given a questionnaire to assess the attractiveness of the LKPD. A smallscale test was conducted at the Minhajuth Thullab Qur'an Science Junior High School in Pekalongan. The results of the response of students to Islamic Based LKPD 87\% with the achieved criterion that is "Very Feasible" this means that the LKPD developed by researchers has interesting criteria to be used as a tool in teaching and learning activities in Class VII students of Qur'an Science Junior High School Minhajuth Thullab Pekalongan.

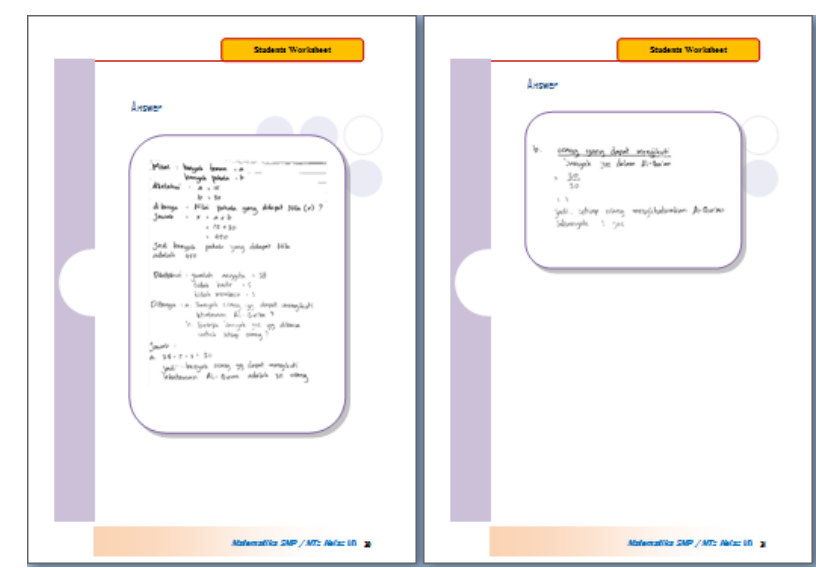

Figure 4. Worksheet Based Islamic Contextual Approach

Students worksheet based Islam integrated or connect the subject matter with the values of Islam and the arguments of the Qur'an and Hadith to improve religious students and a deeper understanding of the material inside, especially in algebraic material.

After conducting a small-scale trial, then the product was tested again to the field trial. This field trial is carried out to convince data and to know product attractiveness widely. Respondents in this large group test amounted to 30 students VII of the Qur'an Science Junior High School Minhajuth Thullab Pekalongan by giving a questionnaire to determine students' responses to the attractiveness of the LKPD. This field trial was carried out in VII Qur'an Science SMP Minhajuth Thullab Pekalongan. the results of students' responses to Islamic-based LKPD were obtained an average of $86 \%$ with the interpretation criteria achieved being "very feasible", this means that LKPD developed by researchers has very interesting criteria to be used as a tool in teaching and learning activities in Participants in VII of the Qur'an Science Junior High School Minhajuth Thullab Pekalongan.

After conducting small group trials and field trials, then the product was tested again to the educator's trial. The educator's test was carried out to convince the data and to know the product attractiveness widely. Respondents in this educator trial were 1 educator of the Qur'an Science Junior High School Minhajuth Thullab Pekalongan by giving a questionnaire to find out the educator's response to the attractiveness of LKPD based on Islamic values. The educator's trial was conducted at the Minhajuth Thullab Qur'an Science Junior High School in Pekalongan. the results of the educator trial on Islamic Based LKPD were obtained an average of $91.4 \%$ with the interpretation criteria achieved namely "Very interesting", this means that the LKPD developed by researchers has very interesting criteria to be used as a tool in the 
activities of the teaching and learning process for class VII of the Qur'an Science Junior High School Minhajuth Thullab Pekalongan.

\section{Product Dessiminate}

After a small group trial and a large trial to find out the attractiveness of LKPD Based on Islamic values for class VII, the product was said to be of very high attractiveness so no repeat trials were conducted. Furthermore, LKPD can be used as a learning resource for students and educators at the Minhajuth Thullab Qur'an Science Junior High School in Pekalongan. In terms of educational facilities, the minimum requirements are due to the lack of maximum teaching staff in preparing teaching materials such as educational equipment, educational media, books and other learning resources that can be attractive when students start learning such as the use of textbooks and LKPD provided by the parties school (Yusminah and Mushawwir, 2014).

The results of observations and interviews with class VII teachers, Mrs. Okta Ayuningtyas, S.Pd with 30 students in one class, found that carried out the learning process in the classroom still centered teachers. Because the role of educators is still more dominant than students in learning activities. Educators deliver the material using lecture, discussion, assignment and question and answer methods. This method is very helpful in learning activities. Learning Activities in the Qur'an Science Junior High School Minhajuth Thullab Pekalongan uses teaching materials provided by the school, namely the 2013 printed print book as a source of material used by educators. Educators have never developed Islamic Based LKPD themselves. But based on the results of preliminary observations obtained, the use of integrated print LKPD has not been developed in the school.

The results of interviews with educators of Class VII of Qur'an Science Junior High School Minhajuth Thullab Pekalongan, Ms. Okta Ayuningtyas, S.Pd, said that teaching educators used teaching materials that had been provided from the school, namely printed books 2013. Educators had never made their own LKPD and developing LKPD based on Islamic values. Especially in print learning in which there are several materials that use worksheets for students to learn independently or in groups. So that in application learning the role of educators is more dominant than students in learning activities.

The results of the validation assessment of the material expert stage 1 experienced an increase in the validation of the material expert stage 2 . The values for the content feasibility aspect in stage 1 obtained an average score equal to the criteria of "very feasible" and at stage 2 the average feasibility score filled with the criteria "Very decent". The presentation aspect in stage 1 obtained an average score equal to the criteria "very feasible" and in stage 2 the average score of presentation aspects was obtained with the criteria of "very high". The average score of the Integrated aspects of Islamic Values in stage 1 is equal to the criteria "feasible" and at stage 2 the average score of Integrated Islamic Values is obtained by the criteria of "very feasible".

\section{CONCLUSION}

The results of the research and discussion can be concluded that in the development of LKPD Based on Islamic values for class VII it is feasible to be used as a learning media. The conclusions that can be drawn from this development research are as follows: Development of LKPD based on Islamic values using a contextual approach to the subject of algebraic form in class VII of the Minhajuth Thullab Qur'an 
Science Junior High School Pekalongan. The product developed is then tested for its feasibility by validity and product testing to determine the extent to which learning motivation and student learning outcomes increase after learning using LKPD media based on Islamic values on algebraic material. The response of teachers to LKPD based on Islamic values using a contextual approach to the subject of algebraic forms obtained a score of $87 \%$ with very interesting criteria. The responses of students to Student Worksheets (LKPD) obtained a score of $88 \%$ with very interesting criteria.

\section{REFERENCES}

Agustin, R., Ambarawati, M., \& Utomo, I. B. (2019). Mathematics Encyclopedia Media As Android Based Learning. 8(09), 4.

Anggraini, Anwar, \& Madang. (2016). Pengembangan Lembar Kerja Peserta Didik (LKPD) Berbasis Learning Cycle 7E Materi Sistem Sirkulasi Pada Manusia Untuk Kelas XI SMA. Jurnal Pembelajaran Biologi, 3(1).

Anwar, M. S. (2015). Efektifitas Pembelajaran PBL (Problem Based Learning) Terhadap Kemampuan Berpikir Kritis Dan Kreatif Siswa Materi Tiga Dimensi [Masters, Universitas Terbuka]. http://repository.ut.ac.id/6912/

Ayuningtyas, 0. (2019, January 3). Interview Guru Matematika Kelas VII SMP Sains Qur'an Pekalongan [Personal communication].

Basuki, \& Wijaya. (2018). The Development of Student Worksheet Based on Realistic Mathematics Education. IOP Conf. Series: Journal of Physics: Conf., Yogyakarta.

Choirudin, C. (2015). Efektifitas Pembelajaran Matematika Dengan E-Learning Berbasis Schoology [Masters, Universitas Terbuka]. http://repository.ut.ac.id/6907/

Choirudin, C. (2017). Efektivitas Pembelajaran Berbasis Schoology. NUMERICAL: Jurnal Matematika Dan Pendidikan Matematika, 101-126. https://doi.org/10.25217/numerical.v1i2.131

Departemen Pendidikan Nasional. (2009). UU Sisdiknas No. 20 Tahun 2003. Sinar Grafika.

Ehwanudin, E., Mispani, M., Choirudin, C., Mahmudi, M., \& Anwar, MS. (2019). Development Of Digital Library Through Student Empowerment Scholarship Of NU Smart Program. International Journal Of Scientific \& Technology Research, 8(11), 3447-3451.

Katz, S., \& Stupel, M. (2015). Promoting Creativity and Self-efficacy of Elementary Students through a Collaborative Research Task in Mathematics: A Case Study. Journal of Curriculum and Teaching, 4(1). https://doi.org/10.5430/jct.v4n1p68

Lubis, M., \& Zubaedi. (2013). Evaluasi Pendidikan Nilai. Pustaka Pelajar.

Munandar. (2015). Pengembangan Lembar Kerja Peserta Didik (LKPD) Berorientasi Nilai Islami Pada Materi Hidrolisis. Jurnal Pendidikan Sains Indonesia, 03(01), 27-37.

Mustafa. (2009). Filsafat Pendidikan Islam: Telaah Epistimologi Ilmu. Jurnal Iqra', 3(1).

Narbuko, C., \& Achmadi, A. (2014). Metode Penelitian. Bumi Aksara.

Ningsih, E. F. (2017). Proses Berpikir Mahasiswa dalam Pemecahan Masalah Aplikasi Integral Ditinjau dari Kecemasan Belajar Matematika (Math Anxiety). Iqra (Educational Journal), 1(2), 191-217.

Omeri. (2015). Pentingnya Pendidikan Karakter Dalam Dunia Pendidikan. Manajer Pendidikan, 9(3).

Retnowati, Fathoni, \& Chen. (2018). Mathematics Problem Solving Skill Acquisition: Learning by Problem Posing or by Problem Solving. Cakrawala Pendidikan.

IJEME, Vol. 3, No. 2, September 2019, 152-161. 
Shafa. (2014). Karakteristik Proses Pembelajaran Kurikulum 2013. Dinamika Ilmu, Samarinda: STAIN Samarinda, 14(1).

Subandi, S., Choirudin C., Mahmudi M., Nizaruddin N., \& Hermanita H.. (2018). Building Interactive Communication with Google Classroom. International Journal of Engineering \& Technology, 7(2.13), 460-463.

Sutarti, T., \& Irawan, E. (2017). Kiat Sukses Meraih Hibah Penelitian Pengembangan. Deepublish.

Syaifuddin. (2017). Pengembangan Lembar Kerja Peserta Didik (LKPD) Berbasis Kontekstual Untuk Meningkatkan Kemampuan Pemecahan Masalah dan SelfEfficacy Matematis. Universitas Lampung.

Wahyudi, A., Zulela, Marini, A., Choirudin, Ayshwarya, B., Nguyen, PT., \& K. Shankar. (2019). Government Policy in Realizing Basic Education Metro. International Journal of Innovative Technology and Exploring Engineering (IJITEE), 8(9S3), 113-116.

Yusminah, H., \& Mushawwir, A. (2014). Pengaruh Penggunaan Lembar Kerja Peserta Didik Berbasis Pendekatan Ilmiah Terhadap Aktivitas dan Hasil Belajar IPA Biologi Kelas VII Peserta Didik SMP Negeri 2 Watampone.

Zakaria, Ismail, \& Kiu. (2015). Pengembangan Instructional Video Berbasis Multimedia Untuk Materi Sistem Koordinat. Prosiding Seminar Nasional Matematika Dan Pendidikan Matematika, UMS. 